\title{
Sustainability and Support for the Ecotourism within Etna Park Area
}

\author{
Sebastiano Patti \\ Department of Environmental, Natural and Geological Sciences, University of Catania, Italy
}

\begin{abstract}
Ecotourism sustainability is more likely to occur when the community is involved in the design of an ecotourism project and also when the community leaders support programs for families to learn more about environmental preservation. The purpose of this study is to how to develop a sustainable ecotourism project within the Natural Etna Park. Basically, the aim of this paper is to asses residents' attitudes of the goals and objectives of an ecotourism project. A 23-item Likert-type attitudinal scale was developed based on the results of a Etna Park project. The study is exploratory. A survey has been carried out using a questionnaire administered throughout a mall-intercept sampling method. Data were randomly split into two groups of the SPSS computer package command. It has been used a factor analysis with varimax rotation above the total amount of the respondents in order to identify the number of factors. The paper produces a valid instrument to assess local residents' perception regarding the development of an ecotourism project within a Regional Natural Park. Without the local residents' support, policy makers are less willing to support the development of any project.
\end{abstract}

Keyword: Etna, ecoturism, sustainability, regional natural park, environmental conservation

\section{Introduction}

Ecotourism contributes both environmental conservation and the economy (Donohoe \& Needham, 2006; Ross \& Wall, 1999; Weaver and Lawton, 2007, Weaver, 2005). Therefore, it is a "responsible travel to natural area, which conserves the environment and sustains the well-being of the local people" (The Ecotourism Society, 1998). This definition has been applied to a lot of nature tourism activities and sometimes it has created confusion as to what constitutes this segment of the nature tourism market. Other authors (Wearing \& Neil, 2009; Honey, 2008; Sirakaya et al., 1999) define ecotourism as a form of tourism activities and development that produces a minimal negative impact on the host environment and an involving commitment to environmental protection and conservation of resources.

To better understand the meaning of ecotourism, it is necessary to take into consideration also the concept of sustainability which refers to management strategy of meeting economic commitments without sacrificing an equal or higher quality of life for future generations (Choi et al., 2006; MacGregor, 1993; Musa et al., 2004; Parker \& Khare, 2005) and also to the ecotourist destination development (Curtin, 2003).

Some considerations have to be made also about the ecotourist. He is a professional who has higher income and education compared to other travellers. Factors influencing the ecotourism market include an ageing tourism demand with travellers possessing better retirement programs and more discretionary income and an increasing awareness about environmental preservation (Meric \& Hunt, 1998).
In addition, taking account of residents' attitudes towards ecotourism is a prerequisite to incorporate their participation (Page \& Dowling, 2002, p. 224). Understanding residents' attitudes towards ecotourism management principles can help planners devise more efficient and appropriate management strategies as they deal with possible conflicts between conservation of local resources and economic development of the area, leading ultimately to more smooth running of ecotourism (Lai \& Nepal, 2006). Giving due consideration to the locals' views on resource usage increases the appropriateness of resource management strategies in ecotourism (Agardy, 1993). The purpose of this study is to how to develop a sustainable ecotourism project. Specifically, the study intends to show how to asses local residents' perceptions of the objective of an ecotourism project within Etna Park.

\section{The Study Area}

The scenario is the Etna's area, within the Province of Catania, where it was established in 1987 a Regional Natural Park: "Etna Park", which involves 20 Municipalities, on territory of $58.095,00$ hectares. This area is famous because of the Volcano, the highest active in Europe, recently declared UNESCO World Heritage Site. Etna is also a mountain with recent lava flows where no form of life has settled yet and very ancient lava flows housing natural formations of Austrian pines, beech trees, and birches. Etna represents a special "astenospheric window" caused by the process of lithospheric convergence between Africa and Eurasia and its structural evolution deeply linked to 
the geodynamics of the Mediterranean basin. With its $135 \mathrm{~km}$ of perimeter, it developed, changed, was destroyed, and reconstructed with several geological events that followed each other throughout many dozens of thousand years.

To protect this landscape marked by the presence of man, Etna Park has been divided into four areas. The "A" area (19,000 ha) is almost all public property, there are no human settlements; the
"B" area (26,000 ha) is partly formed by small private agricultural lots and is characterized by rural houses, shelters for animals, palm groves, and noble houses witnessing the ancient and current human presence. Besides the " $\mathrm{A}$ " and " $\mathrm{B}$ " Park areas, there is a pre-Park area in the " $C$ " and " $D$ " areas $(14,000 \mathrm{ha})$ to guarantee the presence of eventual tourist facilities in the respect of the safeguard of landscape and nature.

\begin{tabular}{|r|l|}
\hline & Municipalities \\
\hline 1 & Adrano \\
\hline 2 & Belpasso \\
\hline 4 & Biancavilla \\
\cline { 2 - 2 } 5 & Bronte \\
\cline { 2 - 2 } & Castiglione di Sicilia \\
\hline 6 & Giarre \\
\hline 7 & Linguaglossa \\
\hline 8 & Maletto \\
\hline 9 & Mascali \\
\hline 10 & Milo \\
\hline 12 & Nicolosi \\
\hline 13 & Pedara \\
\hline 14 & Piedimonte Etneo \\
\hline 15 & Ragalna \\
\hline 16 & Randazzo \\
\hline 17 & S. Alfio \\
\hline 18 & Trecastagni dicodia \\
\hline 19 & Viagrande \\
\hline 20 & Zafferana \\
\hline & \\
\hline
\end{tabular}

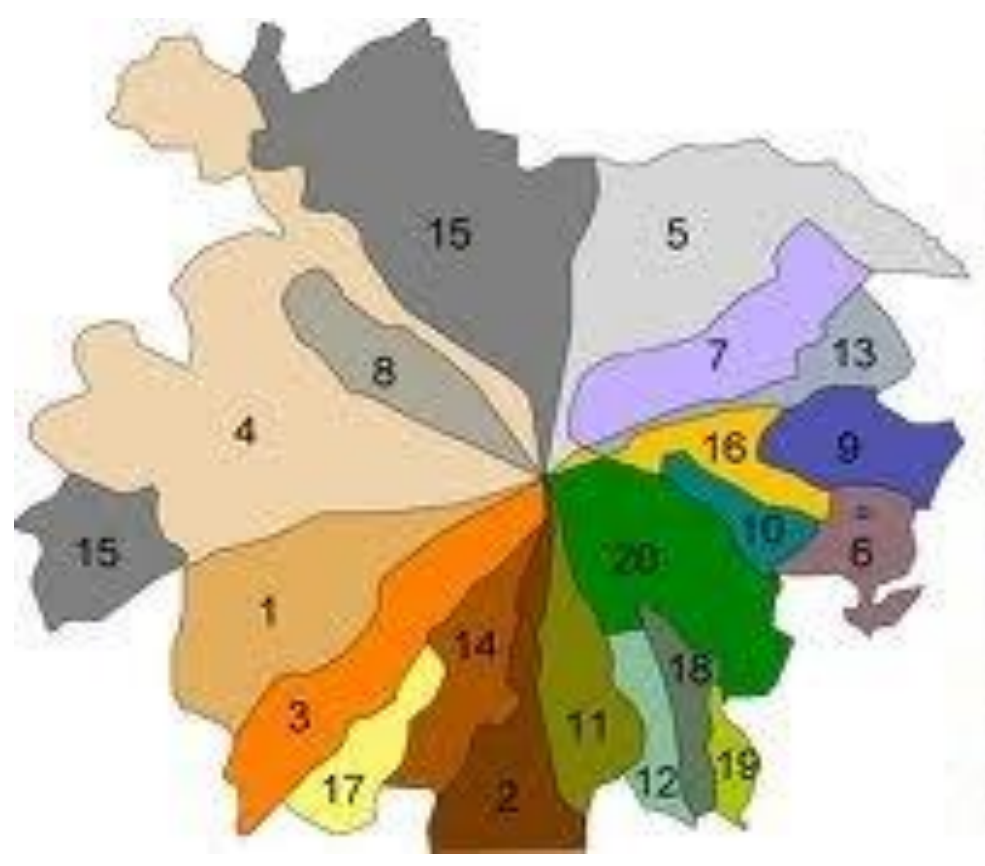

Figure 1. The Municipalities of Etna Park

\section{Methodology and Research Design}

To asses residents' perceptions and attitudes toward the creation and support (Togridou et al., 2006) of the ecotourism project (Byrd, Cárdenas, \& Greenwood, 2008; Andriotis, 2005; McGehee \& Andereck, 2004) of Park of Etna, it needs information that would ascertain local residents' acceptance of the proposed ecotourism project.

Four hypothesis have been specified in factor analysis methodology, they were proposed that are considered essential for assessing residents' support for ecotourism development:

Hypothesis 1: Residents that are environmental consciousness.

Hypothesis 2: Residents that encourage and support developing educational goal and programs that promote conservation for current and future generations.
Hypothesis 3: Residents that demonstrate recognition and support for sustainable economic development in accordance with conservation goals and ecotourism development.

Hypothesis 4: Residents that has to develop ethical conservation regulations and enforcement codes. Each of those hypothesis specified a factor used for the analysis.

\begin{tabular}{|l|l|}
\hline Factor 1 & Community environmental consciousness \\
\hline Factor 2 & Ethical/Moral conservation guidelines \\
\hline Factor 3 & Current Tourism economic benefits \\
\hline Factor 4 & Potential ecotourism economic benefits \\
\hline Factor 5 & Environmental educational objectives \\
\hline
\end{tabular}

An attitudinal rating scale instrument was developed based on the procedures recommended 
by the literature. A 23-item Likert-type attitudinal scale were developed based on the results of an Etna Park project (2010) and input from a focus group of Etna's stakeholders, composed by Etna Park's staff, University ecotourism experts, birding experts.

Initially, a draft of the questionnaire was tested with the focus group of Etna's stakeholders who added four additional questions in adherence with the academic literature, the goals and objectives of the Etna Park. The final questionnaire was administered to local residents intercepted within the main Etna malls, as well as in similar studies that have collected data using a mall-intercept sampling methodology (Vincent \& Thompson, 2002).

The respondents were intercepted by the interviewers at the entrance, so to random select the local residents. The survey data was carried out during the week-ends from the beginning of November to the end of December 2012. A 5-point scale (from $1=$ strongly agree to $5=$ strongly disagree) was used to assess attitudes.

Because of the large sample size, the data were randomly split into two groups of the SPSS computer package command: an original sample of 473 residents and a validation sample of 516 residents. In order to ensure the generalizability of the results to the resident population and to test the comparability and stability of the two factors models, a comparison between the results obtained in the original sample with the validation sample was made.

\section{Data analysis}

To test 4 hypothesis, it has been used the factor analysis with varimax rotation above the total amount of the respondents (473) in order to identify the number of factors (see Table 1).

This hypothesis has been based on a Likert scale with 23 statements and compared with similar previous studies (Zhang \& Lei, 2012; Tsaur, et al., 2006; Dimanche \& Smith, 1996; Bottrill \& Pearce, 1995; Allen et al., 1993; D’Amore, 1993; Ap, 1992).

It has been used a principal component extraction method, to analyse all variance in the items, with varimax rotation. Moreover, Bartlett test of sphericity was used for the overall significance of all correlations within the correlation matrix and so also the Measure of Sampling Adequacy (MSA), calculated for the entire correlation matrix and for each individual variable evaluating the appropriateness of applying factor analysis. Bartlett's test and MSA showed a significant number of nonzero correlations and grouping of these correlations to perform factor analysis for both the original and the validation samples. The scores respectively were $p<.001$ and MSA $=0.80$. They highlighted a significant number of correlations. Cronbach's alpha values were calculated to determine the reliability of each identified dimension (Hair, Black, Babin, \& Anderson, 2010, p. 125). Cronbach Alpha was 0.76, therefore there is an acceptable internal consistency.

Table 1. Resident responses regarding support for the ecotourism project.

\begin{tabular}{lrrr}
\hline & \multicolumn{3}{c}{ Original sample $=463$} \\
Variable & Yes & No & Missing \\
\hline Would you visit Park of Etna? & 363 & 94 & 6 \\
Number & 79.4 & 20.6 & 1.3 \\
$\%$ & & & \\
Would you pay a fee to visit Park of Etna? & 318 & 143 & 2 \\
Number & 69.0 & 31.0 & 0.4 \\
Would you purchase a season pass to visit Park of Etna? & 207 & 243 & 13 \\
Number & 46.0 & 54.0 & 2.8 \\
$\%$ & & & \\
Would you drive 40 kilometres to visit Park of Etna? & 305 & 150 & 8 \\
Number & 67.0 & 33.0 & 1.7 \\
Consider yourself to be a birdwatcher? & 148 & 312 & 3 \\
Number & 32.2 & 67.8 & 0.6 \\
\hline
\end{tabular}

Correlations were bracket together to start the factor analysis. Five factors were selected to obtain at least a minimum of tree data per each factor. The analysis was conducted on 23 statements. Scores equal or more than .30 were considered significant (Hair and Anderson, 2010). Factors with scores equal or more than .40 have been highlighted in bold (Table n. 2). The four factors were verified by the factor analysis of the original sample.
Cronbach's index, although low, is 0.6, which represents an acceptable value for each factor, showing an internal consistency amongst the items. Afterwards, the hypothesis concerning the sustainability of environmental tourism and ecotourism project have been tested. The same procedures were performed on the validation sample confirming results similar to those obtained from the original sample. 
Table 2. Factor analysis above residents' perceptions concerning environmental tourism Original sample $(\mathrm{n}=473)$.

\begin{tabular}{|c|c|c|c|c|c|}
\hline Statements & Factor 1 & Factor 2 & Factor 3 & Factor 4 & Factor 5 \\
\hline Voluntary organizations that foster environmental projects & & & 65 & & \\
\hline Can protect environment and increase job opportunities & & & .58 & & .33 \\
\hline Many people needs recreational services & & & .54 & & \\
\hline The historical sites restoration would promote tourism & & & .53 & & \\
\hline The involvement of the residents in environment boost the tourism & & & .48 & & \\
\hline Tourist activities are part of the Regional restoration plan & .38 & & 47 & & \\
\hline The law is necessary to protect the environment & & & 45 & & \\
\hline The tourism increases the recreational opportunities for residents & & & 45 & & \\
\hline Natural environment is an important driver for tourism & & & .44 & & \\
\hline $\begin{array}{l}\text { Tourist development should be discouraged when violate the } \\
\text { environment }\end{array}$ & & .69 & & & \\
\hline $\begin{array}{l}\text { Govern institutions spare no efforts to decrease the regional } \\
\text { unemployment rate. }\end{array}$ & & .67 & & & \\
\hline It needs to improve citizens culture above the environment. & & .53 & & & \\
\hline Profits are not more important than environment & & .43 & & .36 & \\
\hline The tourism decreases the unemployment rate & .64 & & & & \\
\hline Business services improved thanks to the tourism & .58 & & & & \\
\hline Public utilities quality improved thanks to tourism & .52 & .31 & & & \\
\hline Economic development funds should be spent to promote tourism & & & & .70 & \\
\hline The tourism increases job opportunities & .32 & & & .65 & \\
\hline The Region needs more wildlife reserves & & .34 & & .55 & \\
\hline Mountain dews are considered a good place for families' tours. & & & & & .64 \\
\hline Environment education programs improve natural resources & & & & & .58 \\
\hline Children need to learn about environment & & & .37 & & 49 \\
\hline The environment needs more protection & & & & & .38 \\
\hline Eigenvalue & 1.80 & 2.93 & 4.11 & 1.36 & 1.1 \\
\hline$\%$ of variance & 6.7 & 10.9 & 15.2 & 5.0 & 4.3 \\
\hline$\%$ cumulative vari & 32.8 & 26.1 & 15.2 & 37.8 & 42.1 \\
\hline Cronbach's Alpha index & 0.59 & 0.65 & 0.66 & 0.62 & 0.63 \\
\hline
\end{tabular}

Table 3. Factor analysis above residents' perceptions concerning environmental tourismValidation sample $(\mathrm{n}=516)$.

\begin{tabular}{|c|c|c|c|c|c|}
\hline Statements & Factor 1 & Factor 2 & Factor 3 & Factor 4 & Factor 5 \\
\hline Voluntary organizations that foster environmental projects & & & $\mathbf{7 0}$ & & \\
\hline Can protect environment and increase job opportunities & & & .68 & & \\
\hline Many people needs recreational services & & & .63 & & \\
\hline The historical sites restoration would promote tourism & & & .61 & & \\
\hline The involvement of the residents in environment boost the tourism & & .34 & .52 & & \\
\hline The tourism increases the recreational opportunities for residents & & & .40 & & \\
\hline The law is necessary to protect the environment & & & .39 & & \\
\hline Natural environment is an important driver for tourism & & .62 & & & \\
\hline Tourist activities are part of the Regional restoration plan & & .59 & & & \\
\hline $\begin{array}{l}\text { Tourist development should be discouraged when violate the } \\
\text { environment }\end{array}$ & & .56 & & & \\
\hline $\begin{array}{l}\text { Govern institutions spare no efforts to decrease the regional } \\
\text { unemployment rate. }\end{array}$ & & .40 & & & \\
\hline It needs to improve citizens culture above the environment. & .64 & & & & \\
\hline Profits are not more important than environment & .64 & & & & \\
\hline The tourism decreases the unemployment rate & .45 & & 3.3 & & \\
\hline Business services improved thanks to the tourism & .45 & .43 & & & \\
\hline Public utilities quality improved thanks to tourism & & & & .66 & \\
\hline Economic development funds should be spent to promote tourism & & .35 & & .65 & \\
\hline The tourism increases job opportunities & & & & .51 & \\
\hline The Region needs more wildlife reserves & .35 & & & .45 & \\
\hline Mountain dews are considered a good place for families' tours. & & & & .40 & .33 \\
\hline Environment education programs improve natural resources & & & & & .64 \\
\hline Children need to learn about environment & & & .35 & .38 & .54 \\
\hline The environment needs more protection & .35 & & & & .44 \\
\hline Eigenvalue & 1.63 & 2.53 & 4.46 & 1.30 & 1.2 \\
\hline$\%$ of variance & 6.0 & 9.4 & 16.5 & 4.8 & 4.5 \\
\hline$\%$ cumulative variance & 31.9 & 25.9 & 16.5 & 36.7 & 41.2 \\
\hline Cronbach's Alpha index & 0.59 & 0.58 & 0.69 & 0.59 & 0.55 \\
\hline
\end{tabular}


A stepwise analysis of the factor scores identified the same three factors either in the original or in the validation samples also if in a different rank order, which discriminates between financial and non financial supporters of ecotourism project in the Etna Park. The discriminant factors between original and validation samples are: "Community environmental consciousness", "Environmental educational objectives" and "Potential ecotourism economic benefits", while "Ethical/ Moral conservation guidelines" and "Current tourism economic benefits" did not discriminate between the samples.

Table 4. Discriminant function summary analysis.

\begin{tabular}{|c|c|c|c|c|}
\hline \multirow[b]{2}{*}{ Stepwise Analysis: Factors } & \multicolumn{2}{|c|}{$\begin{array}{l}\text { Original Sample } \\
\quad(\mathrm{n}=473) \\
\text { Structure matrix }\end{array}$} & \multicolumn{2}{|c|}{$\begin{array}{c}\text { Validation Sample } \\
\quad(\mathrm{n}=516) \\
\text { Strucutre Matrix }\end{array}$} \\
\hline & Loadings & Rank & Loadings & Rank \\
\hline Potential Ecotourism Economic Benefits & .643 & 1 & .385 & 3 \\
\hline Environmental Educational Objectives & .558 & 2 & .479 & 2 \\
\hline Community Environmental Consciousness & .479 & 3 & 690 & 1 \\
\hline Ethical/Moral Conservation Guidelines & .032 & 4 & -.012 & 5 \\
\hline Current Tourism Economic Benefits & -.032 & 5 & -.016 & 4 \\
\hline
\end{tabular}

\section{Conclusions and Discussion}

Data analysis showed that most of the local residents would attend project to qualify environment. The $70 \%$ of them declared a willingness to pay to attend ecotourism and green tourism in general.

To asses the local resident attitudes toward acceptance and support the goals of the ecotourism program, it has been performed a factor analysis of the 23 Likert-type scale items that produce five factors for the respondents and the four hypothesis were confirmed in the group of the respondents.

The five factors identified from the factor analysis were used as discriminating variables in a discriminant function model where the criterion is whether the local residents would be willing to pay a fee to attend an ecotourism project.

These factors, considered as necessary for community ecotourism development and sustainability, were confirmed in both the original and validation samples. The factor concerning the current tourism economic benefits represents what local residents consider to be benefits to the community as a result of tourism to the area. Both the original sample and the validation sample produced the same three factors as discriminating between residents willing to pay a fee and those unwilling to pay a fee to attend an ecotourism project.

Resuming, this paper produced a valid instrument to assess local residents' perception, regarding the support of an ecotourism project. It showed also that ecotourism activities were identified to assist a Regional Natural Park in the development of an ecotourism project. Furthermore, an environmentally conscious community would be one that develops ecotourism projects that protect the environment.

The findings provide some implications relevant for the support of ecotourism project in regional natural parks and useful information about the instrument to assess residents' perceptions regarding the support and development of an ecotourism project. An environmentally conscious community would be one that develops ecotourism projects that protect the environment and enhance local development as well as involves residents and promote tourism to the area. Additional jobs could be created throughout other related tourism activities, for instance heritage and cultural tourism or wine and food tourism (Asero \& Patti, 2011).

These results confirm also some points coming out by other researches: residents appear to give stronger support to local tourism when they have more positive perception of its impact (Baral et al., 2008; Andereck \& Vogt, 2000; Perdue, Long, \& Allen, 1990). Accordingly, residents' positive attitudes towards ecotourism, particularly those related to the characteristics and management principles of ecotourism, may subsequently encourage their active involvement in local tourism (Weaver, 2002). Local people benefit by improving the quality of the local environment, which increases the visual attraction for tourists, enhances the aesthetic and recreational values of the environment and, in turn, enriches the residents' quality of life (Zhang \& Lei, 2012, p. 917) and also becomes useful for biodiversity conservation (Kiss, 2004).

\section{References}

Agardy M. T. (1993). Accommodating ecotourism in multiple use planning of coastal and marine protected areas. Ocean and Coastal Management, 20(3): 219 - 239.

Allen L., Hafer H.R., Long P. \& Perdue R.R. (1993). Rural residents' attitudes towards recreation and tourism development. Journal of Travel Research, 31 (4): 29 - 54.

Andereck K. L., \& Vogt C. A. (2000). The relationship between residents' attitudes toward tourism and tourism development options. Journal of Travel Research, 39 (1): $27-36$.

Andriotis K. (2005). Community groups' perceptions of and 
preferences for tourism development: evidence from Crete. Journal of Hospitality and Tourism Research, 29(1): 67 - 90.

Ap J. (1992). Residents' perception on tourism impacts. Annals of Tourism Research, 19: 665 - 690.

Asero V. \& Patti S. (2011). Wine tourism experience and consumer behavior: The case of Sicily. Tourism Analysis, 16 (4): 431 - 442.

Baral N., Stern M. J. \& Battharai R. (2008). Contingent valuation of ecotourism in Annapurna conservation area, Nepal: implications for sustainable park finance and local development. Ecological Economics, 66 (2 - 3): 218 - 227.

Byrd E. T., Cárdenas D. A. \& Greenwood J. B. (2008). Factors of stakeholder understanding of tourism: The case of Eastern North Carolina. Tourism and Hospitality Research, 8(3): 192 - 204

Bottrill C. \& Pearce D. (1995). Ecotourism: Towards a key elements approach to operationalising the concept. Journal of Sustainable Tourism, 3(1): $45-54$

Choi H.C. \& Sirakaya E. (2006). Sustainability indicators for managing community tourism. Tourism Management, 27 (6): $1274-1289$

Curtin S. (2003). Whale-watching in Kaikoura: Sustainable destination development? Journal of Ecotourism 2: 173 - 195.

D'Amore L. J. (1993). A code of ethics and guidelines for socially and environmentally responsible tourism. Journal of Travel Research, 31 (3): 64 - 66.

Dimanche F. and Smith G. (1996). Is ecotourism an appropriate answer to tourism's environmental concerns? Journal of Hospitality and Marketing, 3(4): $67-76$.

Donohoe H.M. \& Needham R.D. (2006). Ecotourism: The evolving contemporary definition. Journal of Ecotourism, 5 (3): $192-210$.

Hair J. F., Black W. C., Babin B. J. \& Anderson R. E. (2010). Multivariate data analysis (7th ed.). New Jersey: Pearson Prentice Hall.

Honey M. (2008). Ecotourism and sustainable development: Who own paradise? (2nd ed.). Washington, DC: Island Press.

Kiss A., (2004). Is community-based ecotourism a good use of biodiversity conservation funds? TRENDS in Ecology and Evolution, 19 (5): 232 - 237.

Lai P. H. and Nepal S. K. (2006). Local perspectives of ecotourism development in Tawushan Nature Reserve, Taiwan. Tourism Management, 27 (6): 1117 - 1129.

MacGregor J. R. (1993). Sustainable tourism development, in M. Khan, M. Olsen and T. Var, (edited by) VNR's Encyclopedia of Hospitality and Tourism, New York, Van Nostrand Reinhold.
McGehee N. G., \& Andereck K. L. (2004). Factors predicting rural residents' support of tourism. Journal of Travel Research, 43(2): 131 - 140 .

Meric H. \& Hunt, J. (1998). Ecotourists' motivational and demographic characteristics: A Case of North Carolina Travelers. Journal of Travel Research, 36 (Spring): 57-61.

Musa G., Hall C.M. \& Higham J.E.S. (2004). Tourism sustainability and health impacts in high altitude adventure, cultural and ecotourism destinations: A case study of Nepal's Sagarmatha National Park. Journal of Sustainable Tourism, 12, (4): $306-331$.

Page S. J. and Dowling R. K. (2002). Ecotourism (themes in tourism). New York: Prentice Hall.

Parker S. \& Khare A. (2005). Understanding success factors for ensuring sustainability in ecotourism development in Southern Africa. Journal of Ecotourism, 4 (1): 32 - 46.

Perdue R. R., Long P. T. \& Allen L. (1990). Resident support for tourism development. Annals of Tourism Research, 17 (4): $586-599$.

Ross S., \& Wall G. (1999). Ecotourism: Towards congruence between theory and practice. Tourism Management, 20(1): $123-132$.

Sirakaya E., Sasidharan V. \& Sonmez S. (1999). Redefining ecotuorism: The need for a supply-side view. Journal of Travel Research, 38 (2): 168 - 172.

The Ecotourism Society (1998). Ecotourism statistical fact sheet. Retrieved from www.ecotourism.org.

Togridou A., Hovardas T. \& Pantis J.D. (2006). Determinants of visitors' willingness to pay for the National Marine Park of Zakynthos, Greece. Ecological Economics, 60: 308 - 319.

Tsaur S-H., Lin Y-C \& Lin J-H (2006). Evaluating ecotourism sustainability from the integrated perspective of resource, community and tourism. Tourism Management, 27: 640-653.

Wearing S. \& Neil J. (2009). Ecotoruism, 2nd edition, Routledge.

Weaver D. B., \& Lawton L. J. (2007). Twenty years on: The state of contemporary ecotourism research. Tourism Management, 28(5), 1168 - 1179.

Weaver D. B. (2005). Comprehensive and minimalist dimensions of ecotourism. Annal of Tourism Research, 32 (2): $439-455$

Weaver D. B. (2002). Hard-core Ecotourists in Lamington National Park, Australia. Journal of Ecotourism, 1(1): 1935 .

Zhang H. \& Lei S.L. (2012). A structural model of residents' intention to participate in ecotourism, the Case of a wetland community. Tourism Management, 33: 916 - 925. 